\title{
OBSERVATIONS ON THE PERIOD OF GESTATION IN WHITE MICE
}

\author{
J. FRANK DANIEL
}

Instructor in Comparative Anatomy, University of California

From the Zoölogical Laboratory, University of Michigan

Preliminary to a study which I am making on whitemice, I have found it necessary to reëxamine in detail their period of gestation. In this examination I have ascertained facts which, so far as I am aware, have not been previously described.

The general statement that the period of gestation in white mice is 21 days, ${ }^{1}$ needs considerable modification. Such may be the case, but the likelihood is against it. In fact it may be said that no unqualified statement can be made as to a definite period of gestation for all mice-since this period depends upon the state of the individual mouse.

My plan of study, which has consisted of isolating the female immediately upon an observed copulation, and of keeping her apart from the male until the birth of her young-has been greatly facilitated by the use of observation cases of glass, in which the mice were kept under almost constant attention during the entire period of gestation. ${ }^{2}$ Under this condition, by observing the moment of copulation and the time of birth, I have been able to determine in many cases the period correct to the hour.

1 Allen, Glover M., 1904. The Heredity of Coat Color in Mice. Proc. Am. Acad. of Arts and Sciences, 40, no. 2 (p. 70).

2 Strictly speaking, the period of gestation is that interval of time elapsing between the act of fertilization and birth. In this paper it will be noted however, that I have used the term rather broadly to cover the period between the act of copulation and birth. 
In a consideration of the subject of gestation mice fall naturally into two well defined groups: (1) those that suckle and (2) those that do not suckle young during pregnancy. The latter class of non-suckling mice includes (a) all cases of females carrying their first litter, and (b) those cases in which copulation took place after the young were weaned, or those cases in which copulation took place and the young were separated from the mother or were early lost. For all such, a definite gestation period of practically 20 days may be stated; and this holds true irrespective of size of litter born.

While 20 days may be considered as the average period for nonsuckling mothers, for suckling mothers the period presents no such regularity. This will be made evident from table 1 , in which ten consecutive cases are considered.

TABLE 1

\begin{tabular}{c|c|c|l|c}
\hline EXAMPLE & $\begin{array}{c}\text { DEBIGNATION OF } \\
\text { FEMALE }\end{array}$ & $\begin{array}{c}\text { NUMBER OF YOUNG } \\
\text { BUCKLED }\end{array}$ & PERIOD OF GEBTATION & NUMBER BORX \\
\hline 1 & F & 10 & 30 days & 9 \\
2 & M & 6 & 24 days & 6 \\
3 & J & 8 & 27 days & 7 \\
4 & L & 3 & 25 days & 5 \\
5 & M & 6 & 24 days 19 hours & 11 \\
6 & H & 3 & 22 days & 5 \\
7 & M & 10 & 30 days 3 hours. & 9 \\
8 & H & 5 & 25 days & 1 \\
9 & J & 5 & 24 days 14 hours & 7 \\
10 & F & 8 & 27 days 15 hours & 8 \\
\hline
\end{tabular}

In table 1 two things stand out prominently: First the marked variability, and second the lengthening, of the period of gestation. From the table it will be seen that not only does one mother differ from another in period of gestation, but the same mother at different times shows a similar variability. As an example of the two cases: $H$ (example 6) went but 22 days from the time of copulation to the birth of her young, while $M$ at one time had a period of 30 days + (example 7$)$. The same mouse $(M)$ at another time, however, had a period of only 24 days (example 2). 
Equally as striking is the lengthening of the period. It is seen that the minimum period of 22 days in the mice under consideration is longer than the period (20 days) given for mice of group 1, while the maximum period in this group sometimes exceeds by onethird the period in group 1.

It is thus evident that for group (2) with variations running from two to ten days, no definite time as a period of gestation can be stated. This does not imply, however, that the period of gestation is not orderly. On the contrary, the variability which in table 1 is so evident, gives place, upon a rearrangement of the data, to striking uniformity.

What is the factor upon which this rearrangement can be made?

From cases of prolonged gestation like 1 and 7, from which large numbers of young resulted, my first impression was that the number born might be a factor in this variability. That this is not the case, however, can be shown conclusively by rearranging the table in order of the number born. In such a rearrangement it is seen that $H$ (example 8 ), which gave birth to the smallest number, went longer than $M$ (example 5), which gave birth to the greatest number.

If on the other hand the number suckled rather than the number born govern the variability in the period of gestation, it would be expected that, given a definite number of suckling young, the period would be practically the same in all cases. This, in fact, is seen to be the case. For mouse $M$ suckling 6 at two different times (examples 2 and 5 ) had in one case a period of 24 days and in the other of 24 days and 19 hours. $J$ and $F$ (examples 3 and 10) suckling 8 each, went 27 days, and 27 days 15 hours, respectively. $F$ and $M$ (examples 1 and 7 ) suckling 10 went 30 days and 30 days 3 hours, respectively.

Moreover, this order is so definite that a series increasing from theminimum to the maximum variation may be constructed thus: $\mathrm{H}$ suckling 3 went 22 days (example 6), J suckling 5 went 24 days + (example 9$)$, F suckling 8 went 27 days + (example 10), and $M$ suckling 10 went 30 days + (example 7 ).

This sequence may be shown to further advantage by rearranging table 1 in order of the number suckled. Such a rearrangement is made in table 2 . 
TABJE 2

\begin{tabular}{c|c|c|l|c}
\hline EXAMPIE & $\begin{array}{c}\text { DEBIGNATION OF } \\
\text { FEMALE }\end{array}$ & $\begin{array}{c}\text { NUMBER OF YOUNG } \\
\text { SUCKLED }\end{array}$ & PERIOD OF GESTATION & NUMBER BORN \\
\hline 1 & H & 3 & 22 days & 5 \\
2 & L & 3 & 25 days & 5 \\
3 & H & 5 & 25 days & 1 \\
4 & J & 5 & 24 days 14 hours & 7 \\
5 & M & 6 & 24 days & 6 \\
6 & M & 6 & 24 days 19 hours & 11 \\
7 & J & 8 & 27 days & 7 \\
8 & F & 8 & 27 days 15 hours & 8 \\
9 & F & 10 & 30 days & 9 \\
10 & M & 10 & 30 days 3 hours & 9 \\
\hline
\end{tabular}

Indeed, the variation in such cases has been found to follow so definite an order that by knowing the time of copulation and the number suckled, I have been able to predict within a day or so when the litter would be born. This, as seen in the table, can be done by adding to an initial period of 20 days a number equal to the number suckled. The number resulting, barring certain irregularities, which seem to be individual in nature, is usually slightly greater than the number of days in the period of gestation. Thus, $20+5$, the number suckled by $\mathrm{J}$, will give her period of gestation in case 4 , and $20+8$ will give her period in case 7 .

In concluding the discussion of this variability, a law may be formulated which for practical purposes is as follows:

The period of gestation, in lactating mothers, varies directly with the number of young suckled.

The cause, and time of occurrence, of the lengthening in the period of gestation is a problem in itself, a more complete investigation of which I shall reserve for a future discussion, but a word concerning it may not be out of place at this time.

If it could be shown, for example, that ovulation were in any way retarded, an effective explanation of the cause of lengthened period would be forthcoming. In this case, however, the lengthening would be previous to the true period of gestation. But 
what factor would be capable of thus causing delay in ovulation? It is a belief that in human beings lactation may thus delay or even prevent ovulation.

But, if lactation delay ovulation and thus increase the period, it may be asked-why should not the delay be of practically equal duration in all cases? Why should a mouse when suckling few young, go a relatively short time and when suckling more, go a longer period of time? Does this not suggest amount of lactation and does not amount suggest nutrition?

If it could be shown that lactation, by robbing the developing young of nourishment, causes them to develop more slowly before birth, as malnutrition may retard development after birth, a second explanation for the delay, equally as effective as that of delay in ovulation, would be at hand. In this case the delay would be in the period between fertilization and birth and not in the act of fertilization. In either case lactation might be the cause of the delay.

But whether the delay is in retarded ovulation, that is, before fertilization, or in nutrition after fertilization, is a problem open to experiment. Reserving a detailed discussion for a future communication on the subject, it may be said that two sources of evidence seem to show that, at least in mice, lactation does not delay ovulation.

By microscopic examination Sobotta, in working over a great deal of material, found that ovulation and parturition occur close to the same time. Lams et Doorme confirm the opinion of Sobotta and add (p. 284), "En somme, la mis-bas, la rupture des follicules mûrs, le rut et l'accouplement se suivent ordinairement très vite." Long, in a paper now in press, shows that ovulation takes place in from $14 \frac{1}{2}$ to $28 \frac{1}{2}$ hours after parturition. From this source the common conclusion is that ovulation is not delayed.

From experimental evidence which I now have it is strongly suggested that, in no way does lactation lengthen the period before fertilization. A case in point may be given in conclusion. A mouse, designated as " $F$ " which in examples 8 and 9, table 2, had two periods of lengthened gestation, gave birth to young and as is usual copulated the same day. At the end of the fourth 
day the last one of her young died from cold. Lactation, in this case, was installed and continued for four days, but that it did not delay fertilization is shown by the fact that the mouse gave birth to young just 20 days after copulation.

\section{BIBLIOGRAPHY}

LAms, H. et Doorme, J. 1907 Maturations et Fécondation de L'oeuf des Mammifèrs. Arch. de Biol., 23, pp. 259-365.

LoNG, J. A. 1910 Maturation of the egg of the :nouse. Carnegie Institution Publication.

SовогіA, J. 1895 Die Befruchtung und Furchung des Eies der Maus. Arch. f. mik. Anat. 45, pp. 15-93. 